\title{
АПОПТОЗ ТА ІМУННЕ ЗАПАЛЕННЯ У ХВОРИХ 3 ГОСТРИМ АОРТАЛЬНИМ СИНДРОМОМ
}

\author{
О. В. Бучнева,
}

к.м.н., доцент кафедри Хірургї̈ №1 ХНМУ, завідуюча кардіохірургічним відділенням ДУ

«Інститут загальної та невідкладної хірургї̈ ім. В.Т. Зайщева», м. Харків, Україна

DOI: https://doi.org/ 10.31435/rsglobal_ws/28022019/6358

\section{ARTICLE INFO}

Received: 28 December 2018

Accepted: 20 February 2019

Published: 28 February 2019

\section{KEYWORDS}

aortic aneurysm, apoptosis,

immunological research.

\begin{abstract}
The growing number of complicated aneurysms of the aorta requires further study of this pathology, the allocation of major pathophysiological components to improve the quality of treatment, prevention of complications of the disease. An urgent work is under way to detect immune-inflammatory reactions and the effects of apoptosis in complicated aortic aneurysms of different localization, to assess the possibility of their effect on perioperative flow and complications in the course of surgical treatment. The immune system and serotonin apoptotic markers have been analyzed in patients who underwent surgical treatment for acute aortic syndrome.
\end{abstract}

Citation: O. В. Бучнева. (2019) Apoptoz ta Imunne Zapalennia u Khvorykh z Hostrym Aortalnym Syndromom. World Science. 2(42), Vol.2. doi: 10.31435/rsglobal_ws/28022019/6358

Copyright: (C) 2019 О. В. Бучнева. This is an open-access article distributed under the terms of the Creative Commons Attribution License (CC BY). The use, distribution or reproduction in other forums is permitted, provided the original author(s) or licensor are credited and that the original publication in this journal is cited, in accordance with accepted academic practice. No use, distribution or reproduction is permitted which does not comply with these terms.

Актуальність. Дуже широко в даний момент розробляються нові теорії етіологічних чинників розвитку аневризм аорти: генетична теорія; теорія протеолітичних ферментів; теорія рідкісних металів $[1,2]$. Так, сучасні теорії розвитку, наприклад, теорія аневризм черевної аорти, припускають, що асептичне запалення виникає як відповідь на фіксацію до судинної стінки черевного відділу аорти деякого не виділеного антигену. Ця відповідь характеризується інфільтрацією аортальної стінки макрофагами, Т- та В-лімфоцитами та активацією протеолітичної системи через продукцію цитокінів [3, 10].

Підвищення активності протеіназ призводить до дезінтеграції білків матриксу. Що в свою чергу, призводить до розвитку аневризматичного ураження аорти $[5,9]$.

Останні імунна молекулярні дослідження висувають ще одну гіпотезу розвитку запальних аневризм черевної аорти. У 1997 році Т.E. Rasmussen зі співавторами виявили у хворих з аневризматичним ураженням аорти генетично детермінований дефект в системі HLA в молекулі HLA - DR, що, на їхню думку, може обумовлювати патологічний імунну відповідь на різні антигени [11].

3 використанням імуногістохімічних методів вдалося з'ясувати, що існує два основних шляхи ініціації апоптозу. Перший реалізується через систему білків TNF, до них відносяться Fas (CD95), TNF-R1, DR-3, DR-4, DR-5. Всі рецептори сімейства TNF мають власний "домен смерті" (FADD) в цитоплазмі клітини. Для його ініціації необхідний фізіологічний ліганд (FasL), що належить до сімейства цитокінів, Fas-L синтезується як трансмембранна молекула, але може існувати і в вільній формі, утвореною під впливом металопротеаз [12].

Аналізувалися дані імунологічного дослідження аневризматичних тканин 3 різною давністю розшарування була виявлена кореляція рівня апоптозу та давності розшарування. Таким чином максимальний рівень апоптозних клітин та Fas був виявлений у хворих 3 
розшаруванням подією менше місяця назад та мінімальний рівень - у хворих, які перенесли розшарування більше року тому [5].

Досліджень щодо індукторів апоптозу в гладко м’язових клітинах (ГМК) судин не так багато. Періодично у виданнях з'являються статті про різні металопротеази, що викликають апоптоз.

Так, асоціацією серцево судинних хірургів Британії та Ірландії було проведено велике дослідження, яке показало, що PGE2 $є$ потужним індуктором апоптозу в ГМК судин та його високий рівень корелює з прогресуванням аневризматичного ураження у пацієнтів 3 малими аневризмами черевної аорти (АЧА). Блокування ж PGE2, прийомом НПЗ3, знижує швидкість прогресування аневризматичного ураження [10].

Накопичений великий досвід хірургічного лікування ускладнень аневризм різної локалізації та етіології, запропоновано чимало методів та модифікацій лікування даної патології. Хірургічне втручання є єдиним ефективним методом лікування розриву аневризм. Проте все зростаючу кількість самих аневризм вимагає подальшого вивчення цієї патології, виділення основних патофізіологічних компонентів для поліпшення якості лікування, профілактики можливого ускладненого перебігу захворювання.

Актуальною $є$ робота по виявленню імунна-запальних реакцій та впливу апоптозу при ускладнених аневризмах аорти різної локалізації, оцінці можливості їх впливу на періопераційний перебіг та ускладнення в процесі хірургічного лікування.

Матеріали та методи. Маркери апоптозу імунного запалення досліджені у 64 хворих 3 ускладненими аневризмами аорти різних локалізацій: аневризми черевної аорти (АЧА) - 24 , аневризми грудної аорти (АГА) - 19 , торакоабдомінальні аневризми аорти (ТААА) - 9, розшаровуючі аневризми аорти (РАА) - 12. У даних пацієнтів супутньої аутоімунної патології не виявлено. Проаналізували показники імунної системи та маркерів апоптозу (нуклеосом) в сироватці у хворих, що надійшли на для хірургічне лікування з приводу гострого аортального синдрому. Визначення вмісту сироваткових імуноглобулінів класів $\mathrm{A}, \mathrm{M}$ и $\mathrm{G}$ здійснювали спектрофотометрична. Для визначення концентрації використовували стандартний набір моноспецифічних антисироваток до імуноглобулінів кожного класу та контрольну сироватку 3 відомим вмістом імуноглобулінів (г/л). Концентрацію сироваткових імуноглобулінів розраховували за калібрувальними графіками, побудованими для кожного класу імуноглобулінів.

Вміст циркулюючих імунних комплексів (ЦІК) у сироватці крові оцінювали спектрофотометрична після інкубації зразків у боратному буфері та поліетиленгліколі.

Визначення вмісту аутоімунних антитіл проводили за тестом на лімфоцит токсичність (класичний метод Терасаки). Для проведення тесту використовували лейкоцитарну суспензію, що готовили з гепаринизованої крові та інкубували з гомологічною сироваткою крові.

Вміст субпопуляцій Т-лімфоцитів $\left(\mathrm{CD}^{+}, \mathrm{CD}^{+}, \mathrm{CD}^{+}\right)$визначали за допомогою непрямого імунофлюоресцентного методу 3 використанням специфічних моноклональних антитіл (МКАТ), мічених FITC (за допомогою вторинної сироватки), які зв'язуються 3 відповідним поверхневим антигеном клітки, позначуваним як CD (кластер диференціювання) $\mathrm{CD}^{+}$(зрілі Т-лімфоцити), $\mathrm{CD}^{+}$(Т-хелпери/індуктори), CD8 ${ }^{+}$(Т-цитотоксичні/супресори). Кількість клітин підраховували за допомогою люмінесцентного мікроскопа. Для оцінки фагоцитарної ланки імунітету досліджували фагоцитарну активність нейтрофільних гранулоцитів у лейкоцитарній суспензії, отриманої з гепаринізованої крові.

3 метою об'єктивізації імунологічних порушень при гострих аортальних синдромах ми застосували методику визначення цитокінів, які відіграють важливу роль в загальній реакції організму на патологічний стан. На наш погляд, найбільш інформативним для оцінки імунного статусу $\epsilon$ визначення рівня фактору некрозу пухлин (TNFa), інтерлейкіну - 6 (IL-6), інтерлейкіну - 8 (IL-8), інтерлейкіну - 10 (IL-10). Важливість і необхідність в дослідженні зазначених цитокінів підтверджується їх властивостями.

Результати та їх обговорення. У реалізації та регуляції апоптозу беруть участь численні фактори. На відміну від різноманіття індукторів апоптозу, головне його прояв деградація хроматину. Її основою служить ферментативне розщеплення ДНК, яке відбувається в кілька етапів 3 формуванням нуклеосом (таблиця 1). 
Таблиця 1. Показники імунного запалення у пацієнтів з гострими аортальними синдромами

\begin{tabular}{|l|c|c|c|c|}
\hline \multirow{2}{*}{ Патологія } & \multicolumn{4}{|c|}{ Досліджувані показники } \\
\cline { 2 - 5 } & СРБ & Кріопреципітин & ШОЕ & Нуклеосоми \\
\hline АГА & $1,8 \pm 0,4$ & Негативно & $21 \pm 1.6$ & $1 / 3 / 3$ \\
& $(25 \%)^{*}$ & & $(20 \%)$ & $(25 \%)$ \\
\hline РАА & $2,2 \pm 0,2$ & $1 / 20$ & $12 \pm 0.7$ & $1 / 5 / 5$ \\
& $(25 \%)$ & $(20 \%)$ & $(20 \%)$ & $(30 \%)$ \\
\hline TААА & $1,4 \pm 0,4$ & Негативно & $15 \pm 1.6$ & $1 / 2 / 3$ \\
& $(37,5 \%)$ & & $(12,5 \%)$ & $(25 \%)$ \\
\hline АЧА & $2,4 \pm 0,3$ & $1 / 20$ & $24 \pm 1.4$ & $4 / 3 / 4$ \\
& $(30,6 \%)$ & $(9,3 \%)$ & $(31,2 \%)$ & $(31,6 \%)$ \\
\hline
\end{tabular}

* - відсоток від загального числа в групі

3 наведеної вище таблиці видно що в кожній групі пацієнтів виявляється не великий відсоток хворих 3 активно поточним імунним запаленням. У пацієнтів 3 розривами аневризмами грудної аорти в $25 \%$ випадків виявлявся високий рівень СРБ, який використовується як класичний маркер запалення. Треба відзначити, що високий рівень цього показника корелював 3 високими титрами нуклеосом. Нуклеосоми або фрагментовано розщеплене ДНК по 50-70 тис. пар нуклеотидів - це головний прояв активного поточного апоптозу. В досліджуваній групі також зазначалося високе значення ШОЕ, проте ні в одному випадку ми не виявили кріопреципітинів.

Особливістю пацієнтів з виявленими імунним запаленням було те, що в анамнезі був відсутній достовірний факт травми, хоча тип аневризматичної поразки, локалізація аневризми свідчили на користь останнього. При аналізі показників в групі з РАА високі рівні СРБ, ШОЕ були виявлені у 25-30\%, що відповідало високому рівню нуклеосом. Однак рівень їх, в порівнянні з групою АГА, був на два порядки нижче. Важливо відзначити, що всі пацієнти 3 високим рівнем нуклеосом мали давність розшарування менше півроку.

У групі пацієнтів з розривами ТААА частота виявлення високого рівня СРБ була вище, ніж в двох попередніх групах. Але підвищений рівень нуклеосом не завжди збігався з високими показниками системного запалення. Нам не вдалося виявити характерної залежності перебігу захворювання у цієї групи пацієнтів.

Пацієнти 3 розривами аневризмами черевної аорти представляли найбільшу складність для оцінки, тому що мали найбільшу кількість супутніх захворювань. Однак ми виявили, що у $30 \%$ пацієнтів з цієї групи є високі рівні СРВ, ШОЕ, що практично завжди відповідало високим титрам нуклеосом. Треба так само відзначити, що в цій групі пацієнтів титри нуклеосом були максимальними.

Аналізуючи гуморальні фактори імунітету, ми розбили їх на дві частини. В першу ми віднесли виявлені патологічні антитіла, у другій проаналізували рівні імуноглобулінів, які обумовлюють антитіло-залежний клітинна-опосередкований цитоліз (таблиці 2-3).

Таблиця 2. Дослідження патологічних антитіл у пацієнтів з гострим аортальним синдромом

\begin{tabular}{|c|c|c|c|c|}
\hline \multirow[t]{2}{*}{ Патологія } & \multicolumn{4}{|c|}{ Досліджувані показники } \\
\hline & АНФ & ЦІК & АКЛ & pANCA \\
\hline $\mathrm{A} Г \mathrm{~A}$ & $\begin{array}{c}1 / 20 \\
(15 \%)^{*}\end{array}$ & $\begin{array}{c}225 \pm 23 \\
(30 \%)\end{array}$ & $\begin{array}{c}39 \pm 3,9 \\
(30 \%)\end{array}$ & $\begin{array}{c}1 / 20 \\
(10 \%)\end{array}$ \\
\hline PAA & $\begin{array}{c}1 / 20 \\
(10 \%)\end{array}$ & $\begin{array}{c}166 \pm 34 \\
(30 \%)\end{array}$ & $\begin{array}{c}29 \pm 1,8 \\
(30 \%)\end{array}$ & $\begin{array}{c}1 / 20 \\
(10 \%)\end{array}$ \\
\hline TAA & $\begin{array}{c}1 / 20 \\
(25 \%)\end{array}$ & $\begin{array}{c}149 \pm 22 \\
(37,5 \%)\end{array}$ & $\begin{array}{c}35 \pm 1,7 \\
(37,5 \%)\end{array}$ & $\begin{array}{c}1 / 20 \\
(25 \%)\end{array}$ \\
\hline АЧА & $\begin{array}{c}1 / 20 \\
(25 \%)\end{array}$ & $\begin{array}{l}259 \pm 34 \\
(37,5 \%)\end{array}$ & $\begin{array}{c}36 \pm 4.7 \\
(46,9 \%)\end{array}$ & $\begin{array}{c}1 / 20 \\
(25 \%)\end{array}$ \\
\hline
\end{tabular}

* - відсоток від загального числа в групі

У всіх групах хворих виявлено патологію. Аналізуючи групу пацієнтів з розривами аневризмами грудної аорти ми виявили, що наявність високих титрів антитіл завжди корелювало з високим титрами нуклеосом. При цьому виділяється група пацієнтів складними 
розривами аневризм протезів та латок, аорто легеневими норицями, у яких, незважаючи на високі показники СРБ та інших факторів запалення, антитіла не виявлялися. $\quad$ У $\quad$ хворих 3 розривами РАА були виявлені значно або сильно виражені позитивні кореляційні зв'язки між давністю розшарування та наявністю в сироватці АНФ, ЦІК, АКС. Треба так само відзначити, що для цієї групи пацієнтів виявлена повна залежність між наявністю антитіл та високими показниками СРБ, кріопреципітинів та ШОЕ.

У групі пацієнтів з розривами ТАА найбільш значимо підвищені та в більшому відсотку випадків величини АКС та ЦІК, що також корелювало з високим рівнем СРБ. Кореляційна залежність між високими рівнями антитіл та нуклеосом хоча і простежувалася, проте титри нуклеосом, як ми вже відзначали вище, були нижче, ніж в групах з розривами АГА та РАА.

Таблиця 3. Дослідження рівня імуноглобулинів у пацієнтів з гострими аортальними синдромами

\begin{tabular}{|c|c|c|c|}
\hline \multirow{2}{*}{ Патологія } & \multicolumn{2}{|c|}{ Досліджувані показники } \\
\cline { 2 - 4 } & $\operatorname{IgG~мг/мл~}$ & $\operatorname{IgA~мГ/мл~}$ & IgM мг/мЛ \\
\hline АГА & $19,3 \pm 4,04$ & $5,6 \pm 1.02$ & норма \\
& $(25 \%)^{*}$ & $2,06 \pm 0.81$ & норма \\
\hline РАА & $16,7 \pm 2,24$ & $(20 \%)$ & норма \\
\hline ТАА & $(30 \%)$ & норма & норма \\
\hline АЧА & $12,7 \pm 1,95$ & $4,9 \pm 2,01$ & $(31.3 \%)$ \\
\hline
\end{tabular}

* - відсоток від загального числа в групі

У хворих з розривами АЧА достовірно позитивно корелювала висока концентрація антитіл та ЦІК з високими рівнями СРБ та ШОЕ. Аналізуючи взаємозв'язки між титрами нуклеосом та антитіл, було виявлено, що є повна кореляція між рівнями титрів ЦІК та АКС 3 нуклеосомами. Треба так само відзначити, що ступінь підвищення цих двох антитіл значно перевищувала інші параметри та виявлялася у більшого відсотка пацієнтів. У той час як високі титри АНФ та pANCA зустрічаються в даній групі пацієнтів, але відсоток їх виявлення на порядок менше ніж в попередніх.

Співвідносячи всі ці показники з рівнями імуноглобулінів в сироватці, виявлено, що має місце підвищення титрів IgG у всіх чотирьох групах пацієнтів 3 позитивними маркерами імунної запалення.

У пацієнтів з розривами АГА на тлі підвищення $\operatorname{IgG}$ було і підвищення титрів $\operatorname{IgA.~У~}$ той час як рівень IgM залишався в межах норми. Порівнюючи ці показники 3 маркерами запалення та титрами антитіл, ми виявили що у всіх пацієнтів з високим рівнем СРБ, ШОЕ, нуклеосом, концентрація IgG була підвищеною. Також взаємозв'язок простежувалася і для титрів антитіл. Інший взаємозв'язок ми отримали для пацієнтів з розривами РАА. Так, на тлі відносно першої групи не великого підвищення IgG, спостерігалось незначне зниження IgA, при нормальних показниках IgM. Порівнюючи ці показники 3 виявленими антитілами, ми виявили, що високі титри IgG завжди корелюють з високими рівнями нуклеосом, СРБ, АКС, ЦІК. У той час як зниження рівня $\operatorname{IgA}$ відзначалося лише у пацієнтів 3 виявленими, крім перерахованих вище, титрами рАNCA та АНФ.

У групі пацієнтів з розривами ТАА виявлено лише незначне підвищення рівня $\operatorname{IgG}$, на тлі нормальних показників IgA та IgM. При аналізі даного чинника з вище переліченими ми відзначили, що підвищення IgG має місце тільки у пацієнтів з високим АНФ, pANCA та нуклеосомами. У пацієнтів же $з$ відсутністю АНФ та pANCA, рівень IgG залишався в межах норми, незважаючи на підвищення СРВ, ШОЕ.

У пацієнтів з розривами АЧА рівень IgG та IgA був значно підвищено, а рівень $\operatorname{IgM}$ залишався в межах норми. Співвідносячи ці показники з титрами антитіл та маркерами запалення. Ми виявили той же кореляційний взаємозв'язок, тобто підвищення IgG має місце у пацієнтів з високими титрами антитіл та високими показниками СРВ, ШОЕ та нуклеосом.

Порушення з боку системи гемостазу та гемореології при різних патологічних станах $\epsilon$ важливим патогенетичним фактором, що визначає перебіг захворювання, його тяжкість, а в 
ряді випадків і його результат. Імунне запалення може включати активацію коагуляційної системи, тромбоцитів, тромбіну. В свою чергу, активація контактної системи може крім активації фібринолізу, запуску коагуляційного каскаду, активувати систему комплементу, утворення брадикініна та активацію нейтрофілів. При аналізі лабораторних даних було виявлено, що вже в до операційному періоді в середньому відзначається достовірне скорочення MHC $(\mathrm{p}<0.005)$ в усіх групах хворих 3 гострими аортальними синдромами. Достовірне зниження АЧТЧ $(\mathrm{p}<0,05)$ зазначалося у хворих 3 аневризматичним ураженням аорти, яке поєднується з оклюзією брахіоцефальних судин та артерій нижніх кінцівок (на 20-25\%), а так само у пацієнтів з високими рівнями маркерів апоптозу та імунного запалення (на 25-30\%).

У всіх спостережуваних хворих було достовірне збільшення у порівнянні з нормою $(\mathrm{p}<0,005)$ рівня фібриногену, збільшення змісту ПДФ та РКФМ. У групах пацієнтів з розривами PAA та TAA рівень збільшення даних показників був тим вище, чим більш вираженими були зміни в імунній системі, та чим вище були показники маркерів апоптозу.

Треба також зазначити, що дані зміни у пацієнтів з розривами РАА залежали від давності розшарування, чим менший термін від моменту розшарування тим більш вираженими були порушення (таблиця 4). Достовірне ( $<0.05)$ зниження АЧТЧ спостерігалося в групі хворих з розривами АЧА, - та у пацієнтів з розривами АГА. В решті груп зміни АЧТЧ носили мінімальний характер. Також у вищевказаних хворих крім АЧТЧ, достовірно знижений та ТЧ $(\mathrm{p}<0,001)$, при цьому показники маркерів апоптозу та імунного запалення (CРВ, АКС, ЦІК, нуклеосоми) значно підвищені, що може свідчити на користь посилення активації фібринолітичної системи крові, вже початково підвищеної, при наявності імунного запалення. У всіх пацієнтів оцінювався стан гемореологічних властивостей крові в до операційному періоді. За результатами дослідження виявлено що для всіх пацієнтів з розривами аневризм $\epsilon$ тенденція до підвищення в'язкості крові при різних умовах потоку (таблиця 5). Найбільш виражене підвищення в'язкості крові на всіх швидкостях зсуву спостерігалося у пацієнтів 3 високими маркерами апоптозу та імунного запалення $(\mathrm{p}<0,001)$.

Таблиця 4. Дослідження стану коагуляційної системи у пацієнтів з гострим аортальним синдромом

\begin{tabular}{|l|l|l|l|l|l|l|}
\hline \multirow{2}{*}{ Патологія } & \multicolumn{6}{l}{ Досліджувані показники } \\
\cline { 2 - 7 } & МНВ & АЧТЧ & ТЧ & \\
\cline { 2 - 7 } & 1 & 2 & 1 & 2 & 1 & 2 \\
\hline AГА & $1,15 \pm 0,02$ & $1,38 \pm 0,02$ & $0,89 \pm 0,02$ & $1,44 \pm 0,03$ & $0,99 \pm 0,01$ & $0,96 \pm 0,02$ \\
\hline PAА & $1,05 \pm 0,02$ & $1,35 \pm 0,02$ & $0,74 \pm 0,02$ & $0,88 \pm 0,02$ & $0,87 \pm 0,01$ & $0.90 \pm 0,01$ \\
\hline TAА & $1,21 \pm 0,03$ & $1,39 \pm 0,02$ & $0,90 \pm 0,03$ & $0,95 \pm 0,03$ & $0,97 \pm 0,02$ & $0.99 \pm 0,02$ \\
\hline АЧА & $1,34 \pm 0,02$ & $1,45 \pm 0,03$ & $0,81 \pm 0,03$ & $0,89 \pm 0,03$ & $0,90 \pm 0,02$ & $1,02 \pm 0,02$ \\
\hline Контроль & \multicolumn{7}{|l|}{$1,21 \pm 0,02$} & $0,94 \pm 0,01$ & \multicolumn{2}{l|}{$1,02 \pm 0,03$} \\
\hline
\end{tabular}

1 - показники у пацієнтів без маркерів апоптозу, 2 - показники у пацієнтів з маркерами апоптозу

Таблиця 5. Дослідження показників в'язкості крові у пацієнтів з гострими аортальними синдромами

\begin{tabular}{|l|c|c|c|c|c|c|}
\hline \multirow{3}{*}{ Патологія } & \multicolumn{6}{|l|}{ Досліджувані показники } \\
\cline { 2 - 7 } & $\begin{array}{c}\text { В'язкість крові при } \\
\text { швидкості зсуву 200 с. }\end{array}$ & \multicolumn{2}{|c|}{$\begin{array}{c}\text { В'язкість крові при } \\
\text { швидкості зсуву 100 с. }\end{array}$} & $\begin{array}{c}\text { В'язкість крові при } \\
\text { швидкості зсуву 20 с. }\end{array}$ \\
\cline { 2 - 7 } & 1 & 2 & 1 & 2 & 1 & 2 \\
\hline АГА & $5,2 \pm 0,03$ & $5,4 \pm 0,03$ & $5,5 \pm 0,03$ & $6,0 \pm 0,03$ & $7,1 \pm 0,03$ & $7,9 \pm 0,03$ \\
\hline PAА & $5,1 \pm 0,02$ & $5,7 \pm 0,02$ & $5,7 \pm 0,02$ & $6,2 \pm 0,02$ & $7,8 \pm 0,02$ & $7,9 \pm 0,02$ \\
\hline TAА & $5,2 \pm 0,02$ & $5,6 \pm 0,02$ & $5,7 \pm 0,02$ & $6,1 \pm 0,02$ & $7,8 \pm 0,02$ & $7,9 \pm 0,02$ \\
\hline АЧА & $5,6 \pm 0,03$ & $6,0 \pm 0,03$ & $5,9 \pm 0,03$ & $6,4 \pm 0,03$ & $8,0 \pm 0,03$ & $8,1 \pm 0,03$ \\
\hline Контроль & $4,9 \pm 0,01$ & \multicolumn{2}{|c|}{$5,5 \pm 0,01$} & \multicolumn{2}{c|}{$6,9 \pm 0,01$} \\
\hline
\end{tabular}

1 - показники у пацієнтів без маркерів апоптозу, 2 - показники у пацієнтів з маркерами апоптозу

Крім в'язкості крові аналізували показники агрегації тромбоцитів. Підвищена агрегація тромбоцитів у хворих з розривами АГА спостерігалася, лише в підгрупі 3 травматичними аневризмами, яка склала $60 \pm 1,4 \%$. У групі хворих з розривами РАA та ТАА підвищення агрегації тромбоцитів зазначалося лише у пацієнтів 3 високими маркерами апоптозу та 
імунного запалення, воно склало $65 \pm 1,3 \%$. У цих же групах була відзначена тромбоцитопенія, імовірно асоційована з аутоімунним процесом. У відповідь на шкідливу дію на ендотелій нуклеосом та імунозапальних клітин та молекул, відбувається активація тромбоцитів. Активовані тромбоцити залучаються до коагуляційна-запального каскаду. Вони взаємодіють між собою, з лейкоцитами, утворюючи мікро згустки та прилипаючи до поверхні ендотелію, що веде до зниження їх кількості в циркулюючої крові та розвитку тромбоцитопенії.

Інтраопераційна травма, гепарин, гіпотермія та інші фактори призводять до додаткової активації тромбоцитів що залишилися. Активовані тромбоцити в руслі вивільняють свій вміст та втрачають здатність до агрегації. Розвивається тромбоцитарна дисфункція, що розглядається як одна 3 причин коагулопатії та кровотеч у інтраопераційно та у післяопераційному періоді.

У всіх пацієнтів з розривами АЧА було відмічена підвищення агрегації тромбоцитів $70 \pm 1,8 \%$ в середньому, проте слід зазначити, що цей показник був в 1,5 раз вище при супутніх імунних змінах та склав $82 \pm 1,8 \%$ у порівнянні з середніми показниками у здорових людей, відповідними $50 \pm 1,2 \%(\mathrm{p}<0.001)$.

Висновки. Виявлення високих титрів таких антитіл як АКС, АНФ, рАNCA спільно 3 ЦІК на тлі активного процесу апоптозу та імунного запалення може свідчити на користь припущення про активацію продуктами апоптозу імунного запалення. Виявлення великих титрів IgG асоційованого з антитілами та нуклеосомами може так само свідчити на користь теорії індукції імунної запалення.

У хворих з ускладненими аневризмами аорти вже до операції є порушення реологічних властивостей крові в основному за рахунок збільшення агрегації формених елементів крові, збільшення в'язкості плазми. Наявність імунного запалення та маркерів апоптозу значно підсилює порушення в системі гемостазу. По всій видимості вплив відсмоктувачів, гемодилюція, гіпотермія, використання компонентів донорської крові на тлі вже наявної до операції активації імунної системи, викликає розвиток запального каскаду, який може супроводжуватися підвищенням проникності капілярного русла, витоком рідини з розвитком тканинного набряку, дисфункцією життєва важливих органів. Саме у цих пацієнтів $є$ схильність до розвитку в післяопераційному періоді коагулопатії та ДВЗ синдрому, поліорганної недостатності.

Отримані нами дані свідчать про те, що посилення апоптозу може бути ключовим механізмом у формування аневризм аорти. Імунне запалення - процес, обумовлений складним каскадом взаємодії гуморальних та клітинних елементів, який може супроводжуватися несприятливими клінічними проявами (ниркова та полі органна недостатність, коагулопатія, респіраторні порушення). Все це повинно враховуватися при розробці стратегії лікування пацієнтів з ускладненими аневризмами аорти.

\section{ЛІТЕРАТУРА}

1. Барышников А.Ю., Шишкин Ю.В.// Иммунологические проблемы апоптоза. - М. 2002.

2. Бокерия Л.А., Самуилова Д.Ш., Аверина Т.Б., Самсонова Н.Н. и пр.// Синдром системного воспалительного ответа у кардиохирургических больных. Бюллетень НЦССХ им. А.Н. Бакулева РАМН. 2004; Том 5, №12, стр. 2-24.

3. Морозов Ю.А., Ройтман С.А.// Гемореологические изменения при реконструктивных операциях на аорте. - Ангиология и сосудистая хирургия. - 2003. - том 9, №3: стр. 26-30.

4. Ярилин А.А.//Апоптоз: природа феномена и его роль в норме и при патологии. Актуальные проблемы патофизиологии: избранные лекции/ Под ред. Б.Б. Мороза. - М. 2001.

5. Ascher E, Jacob T, Hingorani A et al.// Expression of molecular mediators of apoptosis and their role in the pathogenesis of lowerextremity varicose veins. Ann Dermatol Venereol. 2001; V 128: p. 1301-1304.

6. Clancy RM, Kapur RP, Molad Y et al.// Immunohistologic evidence supports apoptosis, IgG deposition, and novel macrophage/fibroblast crosstalk in the pathologic cascade leading to congenital heat block. J Arthit and Rheumat. 2004; N1: p. 173-181.

7. Cooley D.A., Golino A., Frezier O.H. et al.// Single-clamp technique for aneurysms of the descending thoraci aorta: report of 132 consecutive cases. - Eur J Cardiothorac Surg. 2000. N18, p.162-167.

8. Domanovits $\mathrm{H}$, Schilinger $\mathrm{M}$, Mullner $\mathrm{M}$ et al.//Acut phase proteins $\mathrm{n}$ patients with abdominal aortic aneurysms. Atherosclerosis. 2002; N 163: p. 297-302.

9. Jones GT, Phillips VL, Harris EL et al. // Functional matrix metalloproteinase-9 polymorphism (C - 1562T) associated with abdominal aortic aneurysm. J Vase Surg. 2003; N 38: p. 1363-1367.

10. Lesauskaite V., Tanganelli P., Sassi C. et al.// Smooth muscle ceils of the media in the dilatative pathology of ascending thoracic aorta: morphology, immunoreactivity for osteopontin, matrix metalloproteinases, and their inhibitors. - Hum Pathol. - 2001. - V 32, N9: p. 1003-1011. 